\title{
Performance of sunflower cultivars at different seeding periods in central Brazil
}

\section{Desempenho de cultivares de girassol em diferentes épocas de semeadura no Brasil central}

\author{
Marcos Birck¹, Flávio Carlos Dalchiavon ${ }^{1 *}$, Diogo Stasiak', Andréia Fernanda Silva locca1, \\ Rosivaldo Hiolanda', Claudio Guilherme Portela Carvalho
}

\author{
${ }^{1}$ Instituto Federal de Educação, Ciência e Tecnologia de Mato Grosso, Departamento de Agronomia, Campo Novo do Parecis, MT, Brasil \\ Empresa Brasileira de Pesquisa Agropecuária/Embrapa Soja, Londrina, PR, Brasil \\ *Corresponding author: flavio.dalchiavon@cnp.ifmt.edu.br \\ Received in May 18, 2016 and approved in September 28, 2016
}

\begin{abstract}
Sunflower (Helianthus annuus L.) is a very important crop for Brazil, and especially for Chapada do Parecis which is the largest domestic producer, because of its climate and soil conditions are adequate to the development of the specie. The performance of cultivars and sunflower seed sowing periods were evaluated in Central Brazil. Experimental design comprised an $8 \times 5$ factorial randomized complete block, with eight sunflower cultivars (Aguará 06, Aguará 04, MG 305, CF 101, SYN 3950HO, SYN 045, GNZ NEON and HELIO 251) and five decennial seeding periods, with three replicates. Analysis of variance and Scott-Knott's test $(p<0.05)$ were applied. Cultivars GNZ NEON and SYN 045 provide the highest production rates in achenes, with higher value in favor of GNZ NEON. SYN $3950 \mathrm{HO}$ (this with higher value), CF101, MG 305, SYN 045 and Aguará 04 gets the highest oil rates in the achenes, with SYN 045, GNZ NEON, Aguará 04 , CF101 and SYN $3950 \mathrm{HO}$ with the highest oil production. The first seed sowing period is the most productive and the first and fifth periods have the best results for oil productivity. Cultivar GNZ NEON and the first period exceede the others with regard to vegetative and reproductive variables.
\end{abstract}

Index terms: Agronomic characteristics; varietal performance; planting date; Helianthus annuus; plant productivity.

\begin{abstract}
RESUMO
O girassol (Helianthus annuus L.) é uma cultura de grande importância para o Brasil, e especialmente para Chapada do Parecis, que é o maior produtor nacional, em virtude das suas condições edafoclimáticas serem propicias ao desenvolvimento da espécie. Objetivou-se avaliar o desempenho de cultivares e épocas de semeadura do girassol no Brasil Central. O delineamento experimental utilizado foi o de blocos casualizados, em esquema fatorial 8 × 5, sendo oito cultivares de girassol (Aguará 06, Aguará 04, MG 305, CF 101, SYN 3950HO, SYN 045, NEON e HELIO 251) e cinco épocas decendiais de semeadura, com três repetições. Aplicou-se análise de variância e teste Scott-Knott $(p<0,05)$. As cultivares GNZ NEON e SYN 045 proporcionaram maiores produtividades de aquênios, com valor superior em favor da GNZ NEON. A SYN 3950HO (esta com valor superior), CF101, MG 305, SYN 045 e Aguará 04, obtiveram os maiores teores de óleo nos aquênios. A $1^{\text {aa }}$ época

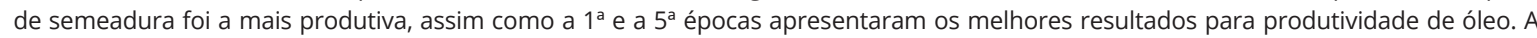
cultivar GNZ NEON e a $1^{1}$ época foram as que se destacaram das demais, tanto para as variáveis vegetativas como para as reprodutivas.
\end{abstract}

Termos para indexação: Características agronômicas; desempenho varietal; períodos de plantio; Helianthus annuus; produtividade vegetal.

\section{INTRODUCTION}

The cultivation of sunflower (Helianthus annuus L.) has been in the limelight due to its agronomic characteristics and to the possibility of being included in crop rotation systems. According to the Report of Agricultural Production, Russia and the Ukraine are the main world producers, featuring $50 \%$ of world production (United States Departament of Agriculture USDA, 2015). Sunflower production is not only on the increase in Brazil due to increasing industrial demands but it is actually an important economical alternative for other grain crops and in the composition of different production systems. The 2015 sunflower harvest in Brazil was small when compared to world production, with only $0.45 \%$ (Usda, 2015). A forecast for Brazilian production was 150,500 tons in an area of 109.4 thousand ha. The state of Mato Grosso, Brazil, produced $77 \%$ of national production, within an area of 86,400 ha, with mean productivity of 1,348 $\mathrm{kg} \mathrm{ha}^{-1}$ (Companhia Nacional de Abastecimento - CONAB, 2015).

Owing to current demands in Brazilian energy segment, sunflower crops are an alternative for the production of quality oil as biofuel and for human and 
animal food. Since it is more tolerant to droughts when compared to corn and sorghum, and due to the great adaptation capacity to different latitudes, longitudes and photoperiods, the cultivation of sunflower is a rotational and succession crop option in several producing regions. Although tolerant to droughts, its production may be severely affected in limited water availability (Castro; Farias, 2005; Backes et al., 2008).

Crop implantation within a determined region during the best period means, in the long run, exposure to better climate conditions, guaranteeing adequate growth and development to plants and higher productivity of achenes (Leite; Brighenti; Castro, 2005). In fact, the seeding period is fundamental for the success of sunflower crops since it is mainly a dependent variable to climatic characteristics of each region. The best seeding period is that which complies with the plant's requirements in its different phases of development, reduces disease risks, especially after flowering, and warrants a good harvest (Leite; Brighenti; Castro, 2005).

Several studies have shown that seeding period and cultivars affect capitulum size and crop productivity (Cadorin et al., 2012; Heldwein et al., 2014). Besides the seeding period, success in the establishment of sunflower cultivation also depends on the cultivars adapted to specific regions. Choice of cultivars is one of the main components of the production system and, due to the genotype $\mathrm{x}$ environment interaction, continuous assessments are required to determine the agronomic behavior of cultivars and their adaptation to different local conditions (Porto; Carvalho; Pinto, 2007). Since there is scanty technical information on cultivars and seeding periods adapted for the local soil and climate conditions, current assay evaluates the performance of sunflower cultivars at different seeding periods in Central Brazil.

\section{MATERIAL AND METHODS}

Current experiment was undertaken in 20142015, at the experimental field of the Federal Institute of Education, Science and Technology of Mato Grosso, campus Campo Novo do Parecis, 13 $400^{\prime} 37^{\prime \prime} \mathrm{S}$ and $57^{\circ} 47^{\prime} 30^{\prime \prime} \mathrm{W}$, altitude $564 \mathrm{~m}$. According to the Brazilian System for Soil Classification (Empresa Brasileira de Pesquisa Agropecuária - EMBRAPA, 2013), soil was Dystrophic Red Latosol. Local climate was $\mathrm{A}_{\mathrm{w}}$, or rather, tropical climate with well-defined dry season between May and September. Figure 1 shows rainfall rates during the experimental period, with $819.5 \mathrm{~mm}$, complying with hydric demands of the crop since it requires an accumulated rainfall rate between 500 and $700 \mathrm{~mm}$, regularly distributed throughout the cycle (Castro; Farias, 2005). The Table also demonstrates temperature registered during the period, with mean rates $30.6 ; 23.5$ and $19.5^{\circ} \mathrm{C}$ respectively for maximum, mean and minimum temperatures.

The texture characteristics of the soil at $0-0.20 \mathrm{~m}$ depth are 506, 134 and $360 \mathrm{~g} \mathrm{~kg}^{-1}$, for clay, silt and sand, respectively. Its chemical characteristics comprise: $\mathrm{pH}$

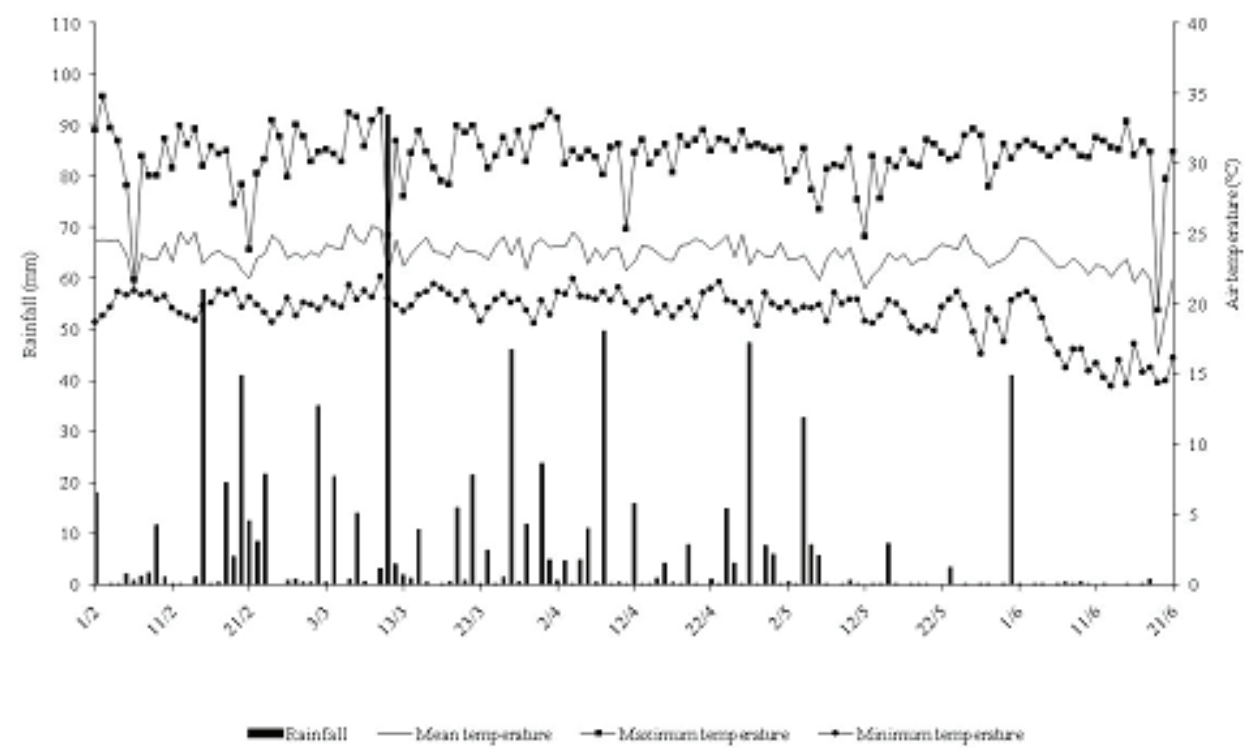

Figure 1. Rainfall, maximum, mean and minimum temperatures, every tem-day period, in the research area between February and June 2015, Campo Novo do Parecis, MT, Brazil. (Source: Dalchiavon et al., 2015) 
$\left(\mathrm{CaCl}_{2}\right)=5.0 ; \mathrm{MO}=35.8 \mathrm{~g} \mathrm{dm}^{-3} ; \mathrm{P}=6.1 \mathrm{mg} \mathrm{dm}^{-3} ; \mathrm{K}$, $\mathrm{Ca}, \mathrm{Mg}$ and $\mathrm{H}+\mathrm{Al}=0.24 ; 2.5 ; 1.0$ and $4.6 \mathrm{cmol}_{\mathrm{c}} \mathrm{dm}^{-3}$, respectively, with $\mathrm{V} \%=45$.

Experiment comprised a randomized block design with eight sunflower cultivars (Aguará 06, Aguará 04, MG 305, CF 101, SYN 3950HO, SYN 045, NEON, and HELIO 251) and five seed sowing periods (01/02/15, 11/02/15, 21/02/15, $03 / 03 / 15$ and $13 / 03 / 15$ ), in three replicates, totaling 120 experimental plots measuring $3.15 \times 5.0 \mathrm{~m}$, comprising seven seeding rows, distant $0.45 \mathrm{~m}$ from one another, with $0.49 \mathrm{~cm}$ between plants, with a total of $15.75 \mathrm{~m}^{2}$ per plot.

Basic fertilization followed Leite, Brighenti and Castro (2005), taking into consideration the chemical analysis of the soil for an expected productivity of $2,000 \mathrm{~kg} \mathrm{ha}^{-1}$, with $42 \mathrm{~kg} \mathrm{ha}^{-1} \mathrm{~N}, 84 \mathrm{~kg} \mathrm{ha}^{-1} \mathrm{P}_{2} \mathrm{O}_{5} ; 30 \mathrm{~kg} \mathrm{ha}^{-1} \mathrm{~K}_{2} \mathrm{O}$ and $0.4 \mathrm{~kg} \mathrm{ha}^{-1}$ $\mathrm{B}$ distributed in the seeding rows with a seven-point fertilizer. Cover fertilization occurred 30 days after seeding (DAS) at each period, for a dose of $20 \mathrm{~kg} \mathrm{ha}^{-1} \mathrm{~N}$ and $1.5 \mathrm{~kg} \mathrm{ha}^{-1}$ B. Seed treatment followed recommendations by industrial trade mark holders. Seeding was done manually at a depth of $0.04 \mathrm{~m}$, with three seeds per hole, with uniform population and expected 45,000 plants ha ${ }^{-1}$. Thinning occurred seven days after emergence (DAE) of the seedlings, with one plant per hole. Pests were generally controlled by constant monitoring, with applications of insecticides when required. Three fungicide applications were undertaken at 20, 35 and 50 DAS for prevention.

Further, $0.5 \mathrm{~m}$ was trimmed from each extremity of the plot and formed the usable area. Five plants within the usable area of the plot at $\mathrm{R}_{5.5}$ (full flowering) were measured for the variables plant height $(\mathrm{PH}, \mathrm{cm})$ and stem diameter (SD, mm). Plant population (PP, plants $h^{-1}$ ) was based on usable area of the plot at $R_{9}$ (physiological maturity). Height ( $\mathrm{HC}, \mathrm{cm}$ ) and length of the capitulum or flower head ( $\mathrm{LC}, \mathrm{cm}$ ) were determined in five plants in the usable area of the plot in $\mathrm{R}_{9}$. Further, 1,000 achenes were collected at random and weighed to calculate the mass of one thousand achenes (MA). The number of achenes per capitulum (NAC) was based on the mass of 1,000 achenes and the productivity of achenes (PA, kg ha ${ }^{-1}$ ) was calculated within the plot's usable area posterior to the capitulum pathway and adjustment of achene humidity to $11 \%$ (humid base hb). Oil rate of achenes (ORA; \%) was calculated with petroleum ether as solvent. Oil productivity (OP; kg $\mathrm{ha}^{-1}$ ) was calculated by oil rate and achene productivity, according Dalchiavon et al. (2015) and Dalchiavon, Malacarne and Carvalho (2016).

Data underwent analysis of variance by F test; when significant, averages were compared by Scott-Knott test $(p<0.05)$, with SISVAR (Ferreira, 2011).

\section{RESULTS AND DISCUSSION}

Cultivars were statistically different for the evaluated vegetable and reproduction variables (Table 1). Similarly, the seed sowing period changed the behavior of the vegetative and reproductive variables, with the exception of ORA. Cultivars' response in some variables was different among the seed sowing periods. Moreover, PP, PH, HC and MA interacted.

Table 1: F rates and statistical significance of variables analyzed in sunflower cultivation, Campo Novo do Parecis, MT, Brazil.

\begin{tabular}{|c|c|c|c|}
\hline \multirow{2}{*}{ Variable } & \multicolumn{3}{|c|}{ Variation source } \\
\hline & Cultivars (C) & Seed sowing period (S) & Interaction $\mathrm{C} \times \mathrm{S}$ \\
\hline Plant Population (PP) & $10.12 * *$ & 23.52 ** & $8.07 * \star$ \\
\hline Plant height (PH) & $60.30 * *$ & $19.63 * *$ & $3.65 * \star$ \\
\hline Stem diameter (SD) & $15.82 * *$ & $6.56 * *$ & $1.23 \mathrm{~ns}$ \\
\hline Height of Capitulum (HC) & $82.16 * \star$ & $41.50 * *$ & $2.79 * \star$ \\
\hline Mass of one Thousand achenes (MA) & 20.24 ** & 2.65 * & 1.89 * \\
\hline Length of Capitulum (LC) & $9.62 * \star$ & $17.78 * \star$ & $1.50 \mathrm{~ns}$ \\
\hline Number of Achenes per Capitulum (NAC) & 5.37 ** & 4.06 ** & $1.40 \mathrm{~ns}$ \\
\hline Productivity of Achenes (PA) & $6.46 * \star$ & $13.30 * *$ & $1.52 \mathrm{~ns}$ \\
\hline Oil Rate of Achenes (ORA) & $22.68 * *$ & $1.81 \mathrm{~ns}$ & $1.57 \mathrm{~ns}$ \\
\hline Oil Productivity (OP) & $4.72 * \star$ & $12.73 * \star$ & $1.59 \mathrm{~ns}$ \\
\hline
\end{tabular}

$\mathrm{ns}, *$ ** not significant $5 \%$ probability and significant at $5 \%$ and $1 \%$ probability, respectively by $\mathrm{F}$ test. 
A relevant variable for crop development is the plant's final population. Bezerra et al. (2014) underscored that increase in seeding density affected negatively the vegetative development of sunflower plants. The development of the tested factors revealed that, since cultivars Aguará 04, SYN 045 and HELIO 251 had their PP altered between seeding periods (Table 2), the establishment of cultivars was highly sensitive to interferences of the environment. Consequently, the correct seeding period should be taken into account. In fact, the

Table 2: Development between cultivars and seed sowing periods for plant population, plant height and capitulum height of the sunflower, Campo Novo do Parecis, MT, Brazil.

\begin{tabular}{|c|c|c|c|c|c|}
\hline \multirow{2}{*}{ Cultivar } & \multicolumn{5}{|c|}{ Seed sowing period } \\
\hline & $1^{\text {st }}$ & $2^{\text {nd }}$ & $3^{\text {rd }}$ & $4^{\text {th }}$ & $5^{\text {th }}$ \\
\hline & \multicolumn{5}{|c|}{ Plant population (one thousand plants $\mathrm{ha}^{-1}$ ) } \\
\hline Aguará 06 & 41.67 Aa & 44.44 Aa & 44.44 Aa & $41.67 \mathrm{Ab}$ & $42.59 \mathrm{Aa}$ \\
\hline Aguará 04 & 44.44 Aa & 44.44 Aa & $24.07 \mathrm{Bd}$ & 43.52 Aa & 44.44 Aa \\
\hline MG 305 & 44.44 Aa & 44.44 Aa & $44.44 \mathrm{Aa}$ & $44.44 \mathrm{Aa}$ & 44.44 Aa \\
\hline CF 101 & $44.44 \mathrm{Aa}$ & $43.52 \mathrm{Aa}$ & $43.52 \mathrm{Aa}$ & 44.44 Aa & 44.44 Aa \\
\hline SYN 3950HO & 44.44 Aa & $42.59 \mathrm{Aa}$ & 44.44 Aa & 44.44 Aa & 44.44 Aa \\
\hline SYN 045 & 44.44 Aa & 44.44 Aa & $28.70 \mathrm{Cc}$ & $38.89 \mathrm{Bb}$ & 44.44 Aa \\
\hline GNZ NEON & 44.44 Aa & 44.44 Aa & 44.44 Aa & 43.52 Aa & 44.44 Aa \\
\hline HELIO 251 & $44.44 \mathrm{Aa}$ & $38.89 \mathrm{Bb}$ & $34.26 \mathrm{Cb}$ & $40.74 \mathrm{Ab}$ & 44.44 Aa \\
\hline \multirow[t]{2}{*}{ Mean / CV (\%) } & \multicolumn{5}{|c|}{$42.59 / 5.56$} \\
\hline & \multicolumn{5}{|c|}{ Height of Plants (cm) } \\
\hline Aguará 06 & $175.60 \mathrm{Ac}$ & 168.07 Aa & 171.13 Aa & $174.73 \mathrm{Ab}$ & $169.00 \mathrm{Ab}$ \\
\hline Aguará 04 & 168.47 Ad & 164.40 Aa & $160.20 \mathrm{Ab}$ & 163.27 AC & 165.87 Ab \\
\hline MG 305 & $189.87 \mathrm{Ab}$ & 168.47 Ba & 179.33 Aa & 165.87 Bc & 168.67 Bb \\
\hline CF 101 & 144.60 Ae & 143.73 Ac & $144.93 \mathrm{Ac}$ & 142.13 Ad & 135.13 Ac \\
\hline SYN $3950 \mathrm{HO}$ & $183.53 \mathrm{Ac}$ & 170.87 Aa & $175.73 \mathrm{Aa}$ & 182.13 Aa & $179.20 \mathrm{Ab}$ \\
\hline SYN 045 & $178.00 \mathrm{Bc}$ & 155.20 Db & 160.33 Db & $170.33 \mathrm{Cb}$ & 192.33 Aa \\
\hline GNZ NEON & 205.47 Aa & $178.60 \mathrm{Ca}$ & $179.60 \mathrm{Ca}$ & 190.60 Ba & 190.13 Ba \\
\hline HELIO 251 & $190.87 \mathrm{Ab}$ & $157.53 \mathrm{Cb}$ & 169.27 Ba & $161.00 \mathrm{Cc}$ & $175.27 \mathrm{Bb}$ \\
\hline \multirow[t]{2}{*}{ Mean / CV (\%) } & \multicolumn{5}{|c|}{170.24 / 3.93} \\
\hline & \multicolumn{5}{|c|}{ Height of Capitulum (cm) } \\
\hline Aguará 06 & 169.47 Aa & $148.00 \mathrm{Ba}$ & $154.33 \mathrm{Ba}$ & 165.07 Aa & $160.53 \mathrm{Aa}$ \\
\hline Aguará 04 & 154.13 Ab & 139.20 Ba & $132.93 \mathrm{Bb}$ & 145.13 Bb & 159.40 Aa \\
\hline MG 305 & $152.47 \mathrm{Ab}$ & $125.40 \mathrm{Bb}$ & 132.27 Bb & $128.87 \mathrm{Bc}$ & $140.93 \mathrm{Ab}$ \\
\hline CF 101 & 108.20 Ac & $92.73 \mathrm{Ac}$ & $94.93 \mathrm{Ad}$ & $93.07 \mathrm{Ad}$ & $95.53 \mathrm{Ac}$ \\
\hline SYN 3950HO & $149.40 \mathrm{Ab}$ & 139.13 Aa & $145.60 \mathrm{Aa}$ & $152.87 \mathrm{Ab}$ & 153.87 Aa \\
\hline SYN 045 & $139.07 \mathrm{Bb}$ & $108.00 \mathrm{Cc}$ & $105.87 \mathrm{Cc}$ & 128.07 BC & 151.13 Aa \\
\hline GNZ NEON & $147.40 \mathrm{Ab}$ & $124.60 \mathrm{Bb}$ & 106.13 Cc & 131.13 Bc & $138.40 \mathrm{Ab}$ \\
\hline HELIO 251 & $142.40 \mathrm{Ab}$ & 100.40 Cc & $90.93 \mathrm{Cd}$ & $117.53 \mathrm{Bc}$ & $130.67 \mathrm{Ab}$ \\
\hline
\end{tabular}

* Similar capital letters on the line and similar small letters in the column are not different by Scott-Knott test ( $p<0.05)$; CV (\%): Coefficient of Variation. 
third period had the highest interferences on the variable PP due to rainfall intensity immediately after seeding, followed by a long drought period with surface sealing which hindered the emergence of plantlets (Figure 1). Smallest PP during the third period was reported for cultivar Aguará 04, whereas no changes in the final plant population occurred during the first and fifth periods.

Cultivar HELIO 251 decreased PP for the second and third periods (Table 2), coupled to a great number of broken plants and fallen capitulum during the physiological maturation phase $\left(R_{9}\right)$, perhaps due to a lower resistance of the stem already referred to by Mello et al. (2006) who associated this phenomenon to a period with better conditions for the occurrence of Alternaria spots. Contrastingly, PP of cultivars Aguará 06, MG 305, CF 101, SYN 3950HO and GNZ NEON was not changed during the seeding period, favoring adequate establishment and demonstrating a longer seeding period for the cultivar analyzed without the occurrence of a negative effect on PP.

Plant height ranged between 135.13 and 205.47 $\mathrm{cm}$, with an average of $170.24 \mathrm{~cm}$ (Table 2). Mean rate was higher than $149.00 \mathrm{~cm}$ reported by Mello et al. (2006) in the region of Santa Maria, state Rio Grande do Sul, Brazil, when they researched the phenological and productive characteristics of sunflower hybrids cultivated at different seed sowing periods. On average, the cultivar GNZ NEON was the longest $(188.88 \mathrm{~cm})$ and CF 101 was shortest at all seeding periods, averaging $142.11 \mathrm{~cm}$. Cultivars MG 305, SYN 045, GNZ NEON and HELIO 251 revealed differences in $\mathrm{PH}$ when seeded at different periods. Although a short height may decrease loss in the harvest, it may enhance cultivation features during the vegetative development. Since decrease in height did not occur gradually as the seed sowing period progressed, this fact disagreed with that reported by Capone et al. (2012) when they analyzed seed sowing periods in the state of Tocantin, Brazil, between March and May. There was no co-relationship between $\mathrm{PH}$ and PP, confirmed by Backes et al. (2008) in their research on the adaptation of sunflower cultivars seeded during two periods of the second harvest in the northern plateau of the state of Santa Catarina, Brazil.

Stem diameter (SD) of sunflower plants averaged $23.96 \mathrm{~mm}$ (Table 3), higher than that obtained by Dalchiavon et al. (2015), or rather, $17.30 \mathrm{~mm}$, when they investigated sunflower cultivate in state of Mato Grosso, Brazil. Significant differences were reported when the cultivars were compared, disagreeing with report by Backes et al. (2008) who failed to detect any differences between cultivars for SD. GNZ NEON had the biggest diameter $(27.12 \mathrm{~mm})$, followed by HELIO 251, with $25.62 \mathrm{~mm}$. As registered by Backes et al. (2008) no co-relationship existed between PP and SD, since Helio 251, with the smallest PP during three periods, did not have a smaller SD. The lowest rate occurred in the fifth period when SD was analyzed according to seed sowing periods (Table 4). The variable alone may not be related to PA, since the third and the fourth periods were the least productive.

Similar to what has been reported for $\mathrm{PH}$, cultivar CF 101 had the lowest HC in all seed sowing periods analyzed (Table 2). The above demonstrated that, similar to SYN 3950HO, there was no difference between seed sowing periods tested for the cultivar under analysis.

Table 3: Stem diameter, length of capitulum and number of achenes per capitulum of sunflower plants according to cultivars, Campo Novo do Parecis, MT, Brazil.

\begin{tabular}{cccc}
\hline Cultivar & Stem diameter $(\mathrm{mm})$ & Length of Capitulum $(\mathrm{cm})$ & Number of achenes per capitulum \\
\hline Aguará 06 & $23.56 \mathrm{c}$ & $16.38 \mathrm{~b}$ & $978 \mathrm{a}$ \\
Aguará 04 & $22.93 \mathrm{c}$ & $17.54 \mathrm{a}$ & $1,069 \mathrm{a}$ \\
MG 305 & $23.80 \mathrm{c}$ & $15.75 \mathrm{c}$ & $894 \mathrm{~b}$ \\
CF 101 & $22.70 \mathrm{c}$ & $15.25 \mathrm{~d}$ & $1,000 \mathrm{a}$ \\
SYN 3950HO & $23.20 \mathrm{c}$ & $15.00 \mathrm{~d}$ & $851 \mathrm{~b}$ \\
SYN 045 & $22.77 \mathrm{c}$ & $15.10 \mathrm{~d}$ & $848 \mathrm{~b}$ \\
GNZ NEON & $27.12 \mathrm{a}$ & $15.79 \mathrm{c}$ & $901 \mathrm{~b}$ \\
HELIO 251 & $25.62 \mathrm{~b}$ & $15.87 \mathrm{c}$ & $1,016 \mathrm{a}$ \\
\hline Mean & 23.96 & 15.83 & 944 \\
\hline CV (\%) & 6.44 & 6.53 & 14.56 \\
\hline
\end{tabular}

* Same letters in the column are not different by Scott-Knott test $(p<0.05)$. CV (\%): Coefficient of Variation. 
On the other hand, Aguará 06 differed among all cultivars at all seed sowing periods. In fact, it had the highest $\mathrm{HC}$ rate regardless of the period. The plant's reduced size may have been advantageous due to low susceptibility to lodging and facility in cultivation treatments. As described by Pivetta et al. (2012), HC is a relevant characteristic in mechanized agriculture. In fact, a more uniform crop favors an adequate harvest, without losses.

Cultivars SYN 045 and GNZ NEON had the highest MA rates in all seed sowing periods analyzed (Table 5). Since the same cultivars had the highest PA, this fact was in disagreement with Heldwein et al. (2014) who concluded that MA was less important for PA(Table 6) than the length of the capitulum (LC). Cultivars SYN 3950HO and HELIO 251 in the first period, Aguará 04 in the third period and MG 305 in the fourth period also had high MA, whereas cultivars Aguará 06, CF 101, SYN 3950HO, GNZ NEON and HELIO 251 failed to show any changes of rates during the different periods of seed sowing. General average for the variable was $37.15 \mathrm{~g}$, which was higher than that reported by Capone et al. (2012), or rather, 34.62 $\mathrm{g}$, in their work with five succession cultivars to soybean in the state of Tocantins, Brazil, and lower than the average $52.03 \mathrm{~g}$ obtained by Silva et al. (2011) in Augusto Pestana, state Rio Grande do Sul, Brazil.

Differences between cultivars occurred in LC (Table 3) contrastingly to reports by Balbinot Junior, Backes and Souza (2009) who concentrated on seed sowing periods of the sunflower in Papanduva, state Santa Catarina, Brazil. Cultivar Aguará 04 provided the biggest

Table 4: Stem diameter, length of capitulum and number of achenes per capitulum of sunflower plants according to seed sowing period, Campo Novo do Parecis, MT, Brazil.

\begin{tabular}{cccc}
\hline Seed sowing period & Stem diameter $(\mathrm{mm})$ & Length of Capitulum $(\mathrm{cm})$ & Number of achenes per capitulum \\
\hline 1st & $24.12 \mathrm{a}$ & $16.74 \mathrm{a}$ & $1,020 \mathrm{a}$ \\
2nd & $24.26 \mathrm{a}$ & $16.33 \mathrm{a}$ & $967 \mathrm{a}$ \\
3rd & $24.49 \mathrm{a}$ & $16.35 \mathrm{a}$ & $952 \mathrm{a}$ \\
4th & $24.40 \mathrm{a}$ & $14.97 \mathrm{~b}$ & $871 \mathrm{~b}$ \\
5th & $22.54 \mathrm{~b}$ & $14.79 \mathrm{~b}$ & $912 \mathrm{~b}$ \\
\hline Mean & 23.96 & 15.83 & 944 \\
\hline CV (\%) & 6.44 & 6.53 & 14.56 \\
\hline
\end{tabular}

* Same letters in the column are not different by Scott-Knott test $(p<0.05)$. CV (\%): Coefficient of Variation.

Table 5: Development between cultivars and seed sowing periods for a mass of one Thousand achenes of sunflower plants, Campo Novo do Parecis, MT, Brazil.

\begin{tabular}{cccccc}
\hline \multirow{2}{*}{ Cultivar } & \multicolumn{5}{c}{ Seed sowing periods } \\
\cline { 2 - 6 } & $1^{\text {st }}$ & $2^{\text {nd }}$ & $3^{\text {rd }}$ & $4^{\text {th }}$ & $5^{\text {th }}$ \\
\hline Aguará 06 & $29.26 \mathrm{Ab}$ & $29.33 \mathrm{Ab}$ & $33.08 \mathrm{Ab}$ & $30.66 \mathrm{Ab}$ & $35.24 \mathrm{Ab}$ \\
Aguará 04 & $32.44 \mathrm{Bb}$ & $30.22 \mathrm{Bb}$ & $44.59 \mathrm{Aa}$ & $33.63 \mathrm{Bb}$ & $36.13 \mathrm{Bb}$ \\
MG 305 & $32.52 \mathrm{Ab}$ & $35.24 \mathrm{Ab}$ & $24.04 \mathrm{Bc}$ & $40.56 \mathrm{Aa}$ & $35.08 \mathrm{Ab}$ \\
CF 101 & $31.61 \mathrm{Ab}$ & $32.61 \mathrm{Ab}$ & $35.55 \mathrm{Ab}$ & $33.77 \mathrm{Ab}$ & $34.38 \mathrm{Ab}$ \\
SYN 3950HO & $36.02 \mathrm{Aa}$ & $35.23 \mathrm{Ab}$ & $34.38 \mathrm{Ab}$ & $34.03 \mathrm{Ab}$ & $39.67 \mathrm{Ab}$ \\
SYN 045 & $40.46 \mathrm{Ba}$ & $50.97 \mathrm{Aa}$ & $49.52 \mathrm{Aa}$ & $48.15 \mathrm{Aa}$ & $44.16 \mathrm{Ba}$ \\
GNZ NEON & $39.85 \mathrm{Aa}$ & $44.11 \mathrm{Aa}$ & $46.27 \mathrm{Aa}$ & $41.51 \mathrm{Aa}$ & $48.26 \mathrm{Aa}$ \\
HELIO 251 & $36.30 \mathrm{Aa}$ & $35.84 \mathrm{Ab}$ & $36.74 \mathrm{Ab}$ & $36.72 \mathrm{Ab}$ & $37.77 \mathrm{Ab}$ \\
\hline Mean / CV (\%) & & \multicolumn{5}{c}{$37.15 / 12.39$}
\end{tabular}

*Equal capital letters on the line and equal small letters on the column do not differ by Scott-Knott test $(p<0.05)$; CV $(\%)$ : Coefficient of Variation. 
capitulum, whereas cultivars CF 101, SYN 3950HO and SYN 045 produced the smallest. Since cultivars SYN 045 and GNZ NEON had the biggest PA and their LC was below the general average of the cultivars (15.83 $\mathrm{cm})$, LC has no direct relationship with PA (Table 6), against Heldwein et al. (2014). However, the rate (15.83 $\mathrm{cm}$ ) coincided with that given by Mello et al. (2006) who reported rates between 12.90 and $20.00 \mathrm{~cm}$. In fact, LC may be taken as an index for the evaluation of sunflower plant development, very similar to PA, even though, in stress conditions, PA may decrease in spite of cultivations revealing well-developed capitulum (Castro; Farias, 2005).

Cultivars Aguará 06, Aguará 04, CF 101 and HELIO 251 had the highest number of achenes per capitulum (NAC), between 978 and 1,069 (Table 3). Cultivar Aguará 04 had the highest NAC $(1,069)$ coupled to the biggest LC (Table 3) even though such relationship was not positive for the other cultivars. It seems that cultivars do not have a strict trend between NAC and LC, although Pivetta et al. (2012) in their studies on six sunflower cultivars in Palotina PR Brazil, have shown a positive co-relationship between these variables. This fact was not corroborated by current analysis. The general average among cultivars for NAC was 944, or rather, within the range reported by Silva et al. (2011), with rates between 487 and 1,543, in Augusto Pestana, state Rio Grande do Sul, Brazil.

The first, second and third seed sowing periods had the highest LC rates and the highest for NAC to the detriment of the fourth and fifth periods (Table 4). As a rule, late periods seem to present capitulum averaging $10 \%$ smaller, with $9 \%$ less achenes per capitulum. The above corroborates data given by Capone et al. (2012) who related this fact to rainfall decrease.

Cultivars SYN $045\left(1,444.77 \mathrm{~kg} \mathrm{ha}^{-1}\right)$ and GNZ NEON $\left(1,537.77 \mathrm{~kg} \mathrm{ha}^{-1}\right)$ provided the highest PA rates (Table 6), whereas Aguará 06 and MG 305 had the smallest, with less than $1,169.82 \mathrm{~kg} \mathrm{ha}^{-1}$. The cultivar with the highest PA rate (GNZ NEON) exceeded by $42 \%$ that of Aguará $06\left(1,083.09 \mathrm{~kg} \mathrm{ha}^{-1}\right)$ which was the less productive, but $5 \%$ higher than PA reported by Pivetta et al. (2012) who obtained a PA of $1,468.75 \mathrm{~kg}$ $\mathrm{ha}^{-1}$. General PA average for cultivars reached 1,292.40 $\mathrm{kg} \mathrm{ha}{ }^{-1}$, close to Brazilian average of $1,376 \mathrm{~kg} \mathrm{ha}^{-1}$ (Conab, 2015).

Cultivars were also different with regard to ORA, with GNZ NEON and HELIO 251, evidencing the lowest rates, provided rates lower than $38.79 \%$ (Table 6). ORA required by the industry should be above $40 \%$ since, according to Oliveira, Castiglioni and Carvalho (2005), the industries provide bonuses to farmers if cultivars have higher rates. In fact, the higher the bonus, the greater is the producers' preference for cultivars with high ORA and good PA.

On the other hand, cultivar SYN3950HO had the highest ORA, exceeding GNZ NEON by $15.3 \%$. According to Table 1, there was no difference for the variable when the seed sowing periods were compared (rates of 41.40 and $41.95 \%$ respectively for the first and fifth periods), in contrast to report by Thomaz et al. (2012) who registered decrease in ORA as sowing periods were reached, when, as a rule, water availability diminished, and to Castro and Farias (2005) who registered that ORA was affected mainly by water

Table 6: Productivity of achenes, oil rate of achenes and oil productivity of sunflower plants according to cultivar, Campo Novo do Parecis, MT, Brazil.

\begin{tabular}{cccc}
\hline Cultivar & Productivity of achenes $\left(\mathrm{kg} \mathrm{ha}^{-1}\right)$ & Oil rate of achenes $(\%)$ & Oil productivity $\left(\mathrm{kg} \mathrm{ha}^{-1}\right)$ \\
\hline Aguará 06 & $1,083.09 \mathrm{c}$ & $40.19 \mathrm{~b}$ & $435.30 \mathrm{~b}$ \\
Aguará 04 & $1,318.57 \mathrm{~b}$ & $42.23 \mathrm{a}$ & $558.32 \mathrm{a}$ \\
MG 305 & $1,169.82 \mathrm{c}$ & $42.80 \mathrm{a}$ & $501.67 \mathrm{~b}$ \\
CF 101 & $1,271.50 \mathrm{~b}$ & $43.45 \mathrm{a}$ & $551.37 \mathrm{a}$ \\
SYN 3950HO & $1,220.77 \mathrm{~b}$ & $43.64 \mathrm{a}$ & $533.86 \mathrm{a}$ \\
SYN 045 & $1,444.77 \mathrm{a}$ & $42.34 \mathrm{a}$ & $613.29 \mathrm{a}$ \\
GNZ NEON & $1,537.77 \mathrm{a}$ & $37.85 \mathrm{c}$ & $584.22 \mathrm{a}$ \\
HELIO 251 & $1,292.91 \mathrm{~b}$ & $38.79 \mathrm{c}$ & $503.31 \mathrm{~b}$ \\
\hline Mean & $1,292.40$ & 41.41 & 535.17 \\
\hline CV (\%) & 17.17 & 4.30 & 18.43 \\
\hline
\end{tabular}

*Similar letters in the column do not differ among themselves by Scott-Knott test $(p<0.05)$. CV (\%): Coefficient of Variation. 
deficit during the achenes filling period. General ORA average between cultivars reached $41.41 \%$, lower than rate obtained by Grunvald et al. (2014) with mean $44.6 \%$ in ten sunflower cultivars.

Oil productivity (OP) may be obtained from PA and ORA. Two distinct statistical groupings were reported for OP (Table 6) in which the first, comprising cultivars Aguará 04, CF 101, SYN 3950HO, SYN 045 and GNZ NEON, provided an average of $568.21 \mathrm{~kg} \mathrm{ha}^{-1}$, and the second, comprising Aguará 06, MG 305 and HELIO 251, provided an average of $480.09 \mathrm{~kg} \mathrm{ha}^{-1}$, which is $15.51 \%$ less than the most oil productive cultivar group with the highest profit.

General mean PA between cultivars was $535.17 \mathrm{~kg}$ ha $^{-1}$ (Table 6), agreeing with rates reported by Silva et al. (2007) who researched two cultivars, within an irrigated system, in Lavras, state Minas Gerais, Brazil, underscoring 467.42 and $663.47 \mathrm{~kg} \mathrm{ha}^{-1}$. Grunvald et al. (2008) investigated several cultivars in a series of assessment assays coordinated by Embrapa between 2004 and 2007, and obtained OP averages between 861 and 1,022 kg ha-1 with PA between 2,021 and 2,245 $\mathrm{kg} \mathrm{ha}^{-1}$, resulting in average ORA rate between 43.80 and $45.52 \%$, or rather, higher than that in current trial. In their assays between 2004 and 2007, Grunvald et al. (2009) revealed that OP averages were higher ( 869 to $1,040 \mathrm{~kg} \mathrm{ha}^{-1}$ ), with mean PA between 2,003 and $2,328 \mathrm{~kg} \mathrm{ha}^{-1}$. The authors registered higher PA averages than national averages, between 1,399 and 1,453 $\mathrm{kg} \mathrm{ha}^{-1}$, for the period (Conab, 2007).

Cultivars may have a good OP performance even with low PA, due to ORA performance. Although cultivar SYN 3950HO did not have a good performance in PA $\left(1,220.77 \mathrm{~kg} \mathrm{ha}^{-1}\right)$, its performance in OP was satisfactory, or rather, $533.86 \mathrm{~kg} \mathrm{ha}^{-1}$ (Table 6), due to the fact that the cultivar had the best ORA results. Therefore, the choice of the cultivar by the farmer should be based on the commercialization policy of sunflower industries when a cultivar is higher in only one evaluated characteristic (Leite; Brighenti; Castro, 2005).

Highest PA rate occurred during the first period (Table 7), whilst the third and fourth periods provided the lowest rates, probably due to the occurrence of the Alternaria leaf spot (Alternaria helianthi), which, coupled to the white mold (Sclerotinia sclerotiorum), is the most severe to the sunflower cultivation in the region. The Alternaria leaf spot becomes more severe in high temperatures and humidity. The choice of the sowing period is critical to decrease damages. Sowing periods in which inflorescence coincides with periods of intense rainfall should be avoided (Leite; Brighenti; Castro, 2005). Due to decrease in rainfall and reduction of diseases, the fifth period recovered production potential and made possible a higher PA than in the previous periods, without differing from the second period. Current analysis did not evaluated resistance to diseases but reported on the Alternaria leaf spot during all the sowing periods. Highest intensity occurred during the third and fourth periods, especially during the flowering and achene filling periods.

As reported by Backes et al. (2008), Cadorin et al. (2012), Capone et al. (2012) and Thomaz et al. (2012) and regardless of the cultivation region, a decrease in PA occurred with the delay of sunflower seed sowing. Consequently, the difference between the first and fourth periods was $405.64 \mathrm{~kg} \mathrm{ha}^{-1}$ (Table 7) or rather, the first period produced $37.19 \%$ more achenes than during the fourth one. In the case of ORA, the first and fifth sowing periods had the best results. The difference between the first and fourth periods was $167.23 \mathrm{~kg} \mathrm{ha}^{-1}$, or a $36.99 \%$ gain on the first period.

Table 7: Productivity of achenes and oil productivity of sunflower plants according to seed sowing period, Campo Novo do Parecis, MT, Brazil.

\begin{tabular}{ccc}
\hline Seed sowing period & Productivity of achenes $\left(\mathrm{kg} \mathrm{ha}^{-1}\right)$ & Oil productivity $\left(\mathrm{kg} \mathrm{ha}^{-1}\right)$ \\
\hline $1^{\text {st }}$ & $1,496.22 \mathrm{a}$ & $619.37 \mathrm{a}$ \\
$2^{\text {nd }}$ & $1,316.57 \mathrm{~b}$ & $547.64 \mathrm{~b}$ \\
$3^{\text {rd }}$ & $1,165.32 \mathrm{c}$ & $471.74 \mathrm{~b}$ \\
$4^{\text {th }}$ & $1,090.58 \mathrm{c}$ & $452.14 \mathrm{~b}$ \\
$5^{\text {th }}$ & $1,393.31 \mathrm{~b}$ & $584.93 \mathrm{a}$ \\
\hline Mean & $1,292.40$ & 535.17 \\
\hline CV (\%) & 17.17 & 18.43 \\
\hline
\end{tabular}

* Similar letters in the column do not differ among themselves by Scott-Knott test $(p<0.05)$. CV (\%): Coefficient of Variation. 


\section{CONCLUSIONS}

Cultivars GNZ NEON and SYN 045 provide the highest production rates in achenes, with higher value in favor of GNZ NEON. SYN 3950HO (this with higher value), CF101, MG 305, SYN 045 and Aguará 04 gets the highest oil rates in the achenes, with SYN 045, GNZ NEON, Aguará 04, CF101 and SYN 3950HO with the highest oil production. The first seed sowing period is the most productive and the first and fifth periods have the best results for oil productivity. Cultivar GNZ NEON and the first period exceede the others with regard to vegetative and reproductive variables.

\section{ACKNOWLEDGEMENTS}

The authors would like to thank the Research Group in Phytothecny (GPF) of the Federal Institute of Education, Science and Technology of Mato Grosso (IFMT), campus Campo Novo do Parecis, for its collaboration in current assay. The authors are also grateful to the Fundação de Apoio à Pesquisa do Estado de Mato Grosso / Foundation for Research Support of the State of Mato Grosso (FAPEMAT - Process No. 460160/2014 and Process No. $157050 / 2014$ ) by granting scientific training scholarship and financial assistance for research.

\section{REFERENCES}

BACKES L. R. et al. Desempenho de cultivares de girassol em duas épocas de plantio de safrinha no planalto norte catarinense. Scientia Agraria. 9(1):41-48, 2008.

BALBINOTJR, A. A.; BACKES, R. L.; SOUZA, A. M. de. Desempenho de cultivares de girassol em três épocas de semeadura no planalto norte catarinense. Scientia Agraria. 10(2):127133, 2009.

BEZERRA, F. T. C. et al. Comportamento vegetativo e produtividade de girassol em função do arranjo espacial das plantas. Revista Ciência Agronômica. 45(2):335-343, 2014.

CADORIN, A. M. R. et al. Características de plantas de girassol, em função da época de semeadura, na Região Noroeste do Rio Grande do Sul. Ciência Rural. 42(10):1738-1743, 2012.

CAPONE, A. et al. Efeito de épocas de semeadura de girassol na safrinha, em sucessão à soja no Cerrado Tocantinense. Revista Ceres. 59(1):102-109, 2012.

CASTRO, C. de; FARIAS, J. R. B. Ecofisiologia do girassol. In: LEITE, R. M. V. B de C.; BRIGHENTI, A. M.; CASTRO, C. (Ed). Girassol no Brasil. Londrina: Embrapa Soja, 2005. p.163-218.
COMPANHIA NACIONAL DE ABASTECIMENTO - CONAB. Avaliação da Safra Agrícola 2006/2007, n. 9. Brasília, Conab, 2007. 22p.

COMPANHIA NACIONAL DE ABASTECIMENTO - CONAB. Acompanhamento de safra brasileira: grãos, v. 2, safra 2014/15, n. 9, Nono levantamento. Brasília:Conab, 2015. 104p.

DALCHIAVON, F. C.; MALACARNE, B. J.; CARVALHO, C. G. P. de. Características agronômicas de genótipos de girassol (Helianthus annuus L.) em segunda safra no Chapadão do Parecis - MT. Revista de Ciências Agrárias. 39(1):177185, 2016.

DALCHIAVON F. C. et al. Relationship between sunflower productivity and soil's chemical properties by geo-statistical techniques. African Journal of Agricultural Research, 10(35):3525-3532, 2015.

EMPRESA BRASILEIRA DE PESQUISA AGROPECUÁRIA EMBRAPA. Sistema brasileiro de classificação de solos. 3. ed. Brasília: Embrapa, 2013. 306p.

FERREIRA, D. F. Sisvar: A computer statistical analysis system. Ciência e Agrotecnologia. 35(6):1039-1042, 2011.

GRUNVALD, A. K. et al. Adaptabilidade e estabilidade de genótipos de girassol no Brasil Central. Pesquisa Agropecuária Brasileira. 43(11):1483-1493, 2008.

GRUNVALD, A. K. et al. Adaptabilidade e estabilidade de genótipos de girassol nos estados do Rio Grande do Sul e Paraná. Ciência e Agrotecnologia. 33(5):1195-1204, 2009.

GRUNVALD, A. K. et al. Adaptabilidade e estabilidade de híbridos de girassol convencional e alto oleico na Região Sul do Brasil. Revista de Ciências Agrárias. 57(3):217223, 2014.

HELDWEIN, A. B. et al. Características de produção e de crescimento de girassol semeado de agosto a fevereiro, em Santa Maria-RS. Revista Brasileira de Engenharia Agrícola e Ambiental. 18(9):908-913, 2014.

LEITE, R. M. V. B. de C.; BRIGHENTI, A. M.; CASTRO, C. de. Girassol no Brasil. Londrina: Embrapa Soja, 2005. 641p.

MELLO, R. et al. Características fenológicas, produtivas e qualitativas de híbridos de girassol em diferentes épocas de semeadura para produção de silagem. Revista Brasileira de Zootecnia. 35(3):672-682, 2006.

OLIVEIRA, M. F. de; CASTIGLIONI, V. B. R.; CARVALHO, C. G. P. de. Melhoramento do girassol. In: LEITE, R. M. V. B de C.; BRIGHENTI, A. M.; CASTRO, C. (Ed). Girassol no Brasil. Londrina: Embrapa Soja, 2005. p. 269-297. 
PIVETTA, L. G. et al. Avaliação de híbridos de girassol e relação entre parâmetros produtivos e qualitativos. Revista Ciência Agronômica. 43(3):561-568, 2012.

PORTO, W. S.; CARVALHO, C. G. P. de; PINTO, R. J. B. Adaptabilidade e estabilidade como critérios para seleção de genótipos de girassol. Pesquisa Agropecuária Brasileira. 42(4):491-499, 2007.

SILVA, M. D. L. et al. Crescimento e produtividade do girassol cultivado na entressafra com diferentes lâminas de água. Revista Brasileira de Engenharia Agrícola e Ambiental. 11(5):482-488, 2007.
SILVA, J. A. G. da et al. Distância genética em genótipos de girassol. Revista Brasileira de Agrociência. 17(3-4):326337, 2011.

THOMAZ, G. L. et al. Produção do girassol e teor de óleo nas sementes em diferentes épocas de semeadura no CentroSul do Paraná. Ciência Rural. 42(2):203-208, 2012.

UNITED STATES DEPARTAMENT OF AGRICULTURE - USDA. Foreign Agricultural Service. World Agricultural Production. Circular Series WAP 9-15 September 2015. Washington, 2015b. Available in: <http://www.fas.usda. gov/.> Access in: 16/9/2015. 